\title{
Extrication techniques of entrapped car crash victims: a scoping review*
}

\author{
Técnicas de extração de vítimas de colisão automobilística encarceradas: revisão de escopo \\ Técnicas para extraer víctimas de accidentes automovilísticos encarcelados: revisión del alcance
}

How to cite this article:

Santos Júnior H, Giacon-Arruda BCC, Larrosa S, Andrade AR, Teston EF, Ferreira Júnior MA. Extrication techniques of entrapped car crash victims: a scoping review. Rev Esc Enferm USP. 2021;55:e20210064. https://doi.org/10.1590/1980-220X-REEUSP-2021-0064

\author{
Hamilton Santos Júnior ${ }^{1}$ \\ iD Bianca Cristina Ciccone \\ Giacon-Arruda ${ }^{1}$ \\ (iD) Sarah Larrosa ${ }^{2}$ \\ (iD) André Rodrigues de Andrade ${ }^{3}$ \\ (iD) Elen Ferraz Teston ${ }^{1}$ \\ (iD) Marcos Antonio Ferreira Júnior ${ }^{1}$

\footnotetext{
* Extracted from the dissertation: "Construção e validação de conteúdo de fluxograma para extração de vítimas de colisão automobilística”, Universidade Federal de Mato Grosso do Sul, 2021.

${ }^{1}$ Universidade Federal de Mato Grosso do Sul, Instituto Integrado de Saúde, Programa de Pós-Graduação em Enfermagem, Campo Grande, MS, Brazil.

${ }^{2}$ Universidade Federal de Mato Grosso do Sul, Instituto Integrado de Saúde, Curso de Enfermagem, Campo Grande, MS, Brazil.

${ }^{3}$ Corpo de Bombeiros Militar do Distrito Federal, Grupamento de Atendimento de Emergência Pré-Hospitalar, Brasília, DF, Brazil.
}

\begin{abstract}
Objective: to summarize the extrication techniques of entrapped car crash victims with potential spinal injury. Method: a literature review study, of scoping review type, using the MEDLINE/PubMed, CINAHL, Scopus, Science Direct, Web of Science, Cochrane Library and gray literature data sources, without time frame, with studies that addressed extricating techniques extrication of entrapped car crash victims. Results: a total of 33 studies were included that enabled identifying and summarizing the different types of extrication and respective devices for extrication of entrapped car crash victims, indicated according to injury assessment and the victim's clinical condition. All pointed to the need for techniques to maintain neutral alignment and prevent spine twists. Conclusion: this study indicated that injury assessment with an emphasis on the victim's clinical condition provides a coherent decision-making regarding the technique and device to be used. However, carrying out other comparative studies between existing techniques may help in the decision-making process more assertively.
\end{abstract}

\section{DESCRIPTORS}

Accidents, Traffic; Spinal Cord Injuries; Methods. 


\section{INTRODUCTION}

Annually, traffic accidents are responsible for the death of about 1.35 million people worldwide ${ }^{(1)}$. The damage resulting from these accidents range from materials to those that seriously impact human health, including the occurrence of deaths. Although the economic costs associated with traffic accidents are variable, it is estimated that annual expenditures in low- and middle-income countries exceed $\$ 100$ billion $^{(2)}$.

As a result of this scenario, pre- and in-hospital emergency services are responsible for a continuous care of car accident victims who have injuries of different severity. Thus, care is systematized through the use of instruments that assess the severity of the clinical patterns presented, type and anatomical location of injuries and prognosis. Although there are variations in the structure of these instruments, they make it possible to predict how quickly a victim should receive definitive treatment ${ }^{(3)}$.

In the context of car accidents, despite this assessment of the victim, the severity of the clinical condition and the possible injuries, an individual's entrapment (imprisonment) inside the vehicle becomes an important obstacle for prehospital care (PHC). This event influences fast transportation and access to definitive treatment and adds factors of concern to the care team, related to the existence of possible spinal injuries, as well as the possibility of secondary injury in the process of an individual's extraction and extrication ${ }^{(4)}$.

The extrication of a car accident victim, known as vehicular extrication, is defined as the process of treating, conditioning, removing or releasing entrapped victims in vehicles ${ }^{(5-6)}$. It comprises the following steps: scene assessment and security; stabilization; glass management; initial access; full access; patient immobilization; and final extrication ${ }^{(7)}$.

Extraction is one of the last stages of the extrication process and consists of removing an automobile collision victim from the vehicle ${ }^{(8)}$. However, the best practices in vehicle rescue, especially the extrication of victims, are still poorly studied, which demonstrates weakness in relation to evidence-based practice (EBP). This condition may be associated with the weakness of protocols and flowcharts that systematize the care of entrapped victims with potential spinal injury ${ }^{(7)}$.

Furthermore, studies that summarize the main extrication techniques, the use of devices and their best application are still incipient. In view of this scenario, and the importance of an EBP, the development of studies that support the best choice of extrication techniques and the use of the best devices in the care of these victims becomes important. In this sense, this study aims to summarize the extrication techniques of entrapped car crash victims with potential spinal injury.

\section{METHOD}

This is a literature review study, of scoping review (SR) type, based on the proposed theoretical framework ${ }^{(9)}$ and developed by the Joanna Briggs Institute (JBI) ${ }^{(10)}$. It was conducted and reported according to the assumptions of Preferred Reporting Items for Systematic Reviews and Meta-Analyses extension for Scoping Reviews (PRISMA-ScR) $)^{(11)}$.
The study was developed according to the following steps: research question or guiding question elaboration; relevant study identification; study selection; data extraction; synthesis and grouping of results; and dissemination ${ }^{(10)}$.

The guiding question of this review was formulated using the PCC strategy: P - Population; C - Concept; C - Context ${ }^{(10,11-12)}$, with the following definitions: $\mathrm{P}$ - entrapped automobile collision victims with potential spinal injury; $\mathrm{C}$ - extrication techniques and $\mathrm{C}-\mathrm{PHC}$. With this mnemonic combination, the following guiding question was defined: what techniques are available for extrication of entrapped automobile collision victims with potential spinal injury?

Before starting the development of this study, a search was carried out on the Open Science Framework, JBI Clinical Online Network of Evidence for Care and Therapeutics (CONNECT + ), Database of Abstracts of Reviews of Effects (DARE), The Cochrane Library and the International Prospective Register of Ongoing Systematic Reviews (PROSPERO) sites, in order to identify similar reviews research and avoid duplicates. Thus, as no similar studies were found, this SR was registered in the Open Science Framework (OSF) under protocol osf.io/c689x/.

\section{Publication Search Methods}

The following electronic data sources were used to search and identify the studies: Medical Literature Analysis and Retrieval System Online (MEDLINE/PUBMED - CentralPMC); Cumulative Index to Nursing and Allied Health Literature (CINAHL - Ebsco); SCOPUS (Elsevier); Science Direct (Elsevier); Web of Science Core Collection (Clarivate Analytics); Embase (Elsevier); and Cochrane Library. Access to these sources was performed through the Journal Portal of the Coordination for the Improvement of Higher Education Personnel (CAPES - Coordenação de Aperfeiçoamento de Pessoal de Nivel Superior) using the Universidade Federal do Mato Grosso do Sul (UFMS) proxy.

For the gray literature search, the following data sources were defined: Brazil - Theses and Dissertations Portal for CAPES, Brazilian Digital Library of Theses and Dissertations, Universidade de São Paulo digital Thesis and Dissertation Library and UFMS Thesis and Dissertation Repository; Portugal Open Access Scientific Repository of Portugal (RCAAP); South Africa - National Theses and Dissertations (ETD Portal); Mundo-Cyberthesis; Australia and New Zealand - National Library of Australia (Trove); European Continent - Europe portal - E-theses (DART) and the Information System Opengrey; Canada - Theses Canada; United Kingdom Electronic Thesis Online Service (EThOS); Sweden and other Scandinavian countries - Academic Archive Online (DIVA).

To identify the best descriptors, keywords and synonyms, a search process for articles related to the theme was carried out. After that, a research protocol was constructed consisting of the study question, PCC strategy, descriptors and search strategy according to the specifics of each of the data sources. It was built, tested and exhaustively adapted until it presented search sensitivity capable of identifying studies that responded to the proposed objective.

In this way, the descriptors and keywords were defined (Chart 1) and combined using the Boolean operators AND 
Chart 1 - Subject descriptors located in $\mathrm{MeSH}^{*}$ for research question components according to PCC** strategy - Campo Grande, MS, Brazil, 2021.

\begin{tabular}{|l|l|l|}
\hline Strategy & Components & Descriptors/Keywords \\
\hline P - Population & $\begin{array}{l}\text { Entrapped automobile collision victims with potential spinal } \\
\text { injury. }\end{array}$ & $\begin{array}{l}\text { Accidents, traffic; motor vehicles spinal cord injuries; spinal cord; spinal } \\
\text { injuries; wounds and injuries. }\end{array}$ \\
\hline C - Concept & Extrication techniques. & $\begin{array}{l}\text { Immobilization; restraint, physical; transportation of patients; stretchers; } \\
\text { moving and lifting patients; extrication. }\end{array}$ \\
\hline C - Context & PHC***. & Emergency medical services; rescue work. \\
\hline
\end{tabular}

*MeSH: Medical Subject Headings; ** PCC: Population, Concept, Context; *** PHC: prehospital care.

Chart 2 - Databases, descriptors and search strategies - Campo Grande, MS, Brazil, 2021.

\begin{tabular}{|c|c|}
\hline Databases & Descriptors and keyword/Search strategies \\
\hline MEDLINE/PUBMED & $\begin{array}{l}((((\text { emergency medical services[MeSH Terms] }) \text { OR rescue work[MeSH Terms])) AND }(((((\text { immobilization[MeSH Terms]) OR } \\
\text { restraint, physical[MeSH Terms]) OR transportation of patients[MeSH Terms]) OR stretchers[MeSH Terms]) OR (moving and lifting } \\
\text { patients[MeSH Terms] })) \text { OR extrication[Text Word])) AND ((((spinal cord injuries[MeSH Terms]) OR spinal cord[MeSH Terms]) } \\
\text { OR spinal injuries[MeSH Terms]) OR (wounds and injuries[MeSH Terms]))) AND ((accidents, traffic[MeSH Terms]) OR motor } \\
\text { vehicles[MeSH Terms]) }\end{array}$ \\
\hline CINAHL & $\begin{array}{l}\text { (MH motor vehicles OR MH accidents, traffic) AND ((MH spinal cord injuries OR MH spinal cord OR MH spinal injuries OR MH } \\
\text { (wounds and injuries)) AND (MH immobilization OR MH restraint, physical OR MH transportation of patients OR MH patient } \\
\text { handling OR TX stretcher* OR TX extrication) AND (MH emergency medical services OR MH rescue work) }\end{array}$ \\
\hline SCOPUS & $\begin{array}{l}\text { (KEY ("traffic accident*" OR "motor vehicl*") AND KEY ("spinal cord injur*" OR "spinal cord" OR "spinal injuri*" OR "wounds and } \\
\text { injur*") AND KEY (immobilization OR "physical restraint" OR "transportation of patient*" OR "stretcher*" OR "moving and lifting } \\
\text { patient*" OR extrication) AND KEY ("emergency medical servic*" OR "rescue work")) }\end{array}$ \\
\hline WEB OF SCIENCE & $\begin{array}{l}\text { TS }=(\text { "traffic accident*" OR "motor vehicl*") AND TS=("spinal cord injur*" OR "spinal cord" OR "spinal injur*" OR "wounds and } \\
\text { injur*") AND TS=(immobilization OR "physical restraint" OR "transportation of patient*" OR "stretcher*" OR "moving and lifting } \\
\text { patient*" OR extrication) AND TS=("emergency medical servic*" OR "rescue work") }\end{array}$ \\
\hline SCIENCE DIRECT & $\begin{array}{l}\text { ("traffic accidents" OR "motor vehicles") AND ("spinal cord injuries" OR "spinal cord" OR "wounds and injuries" OR "spinal } \\
\text { injury") AND (immobilization OR "physical restraint" OR "transportation of patients" OR stretchers OR "moving and lifting patients" } \\
\text { OR extrication) AND ("emergency medical services" OR "rescue work") }\end{array}$ \\
\hline EMBASE & $\begin{array}{l}\text { ('traffic accident*' OR 'motor vehicl*') AND ('spinal cord injur*' OR 'spinal cord'/exp OR 'spinal cord' OR 'spinal injuri*' OR 'wounds } \\
\text { and injur*') AND ('immobilization'/exp OR immobilization OR 'physical restraint'/exp OR 'physical restraint' OR 'transportation of } \\
\text { patient*' OR 'stretcher*' OR 'moving and lifting patient*' OR extrication) AND key AND ('emergency medical servic*' OR 'rescue } \\
\text { work'/exp OR 'rescue work') }\end{array}$ \\
\hline
\end{tabular}

and/or OR. The descriptors and search strategy used for each data source are described in Chart 2. The search in all data sources took place on the same day by two researchers (HSJ; SL) on May 5, 2020, except in the Embase base, which occurred on August 5,2021, due to its access, through the UFMS proxy, having been allowed in 2021. A new search was carried out in all data sources as of September 14, 2021.

\section{Selection Criteria and Procedures}

Scientific articles, case studies, literature reviews, book chapters, guidelines and protocols, theses and dissertations, with no time limits, that addressed the extrication techniques of entrapped automobile collision victims were included. Editorials, letters to the editor, expert opinion, abstracts, correspondence, monographs and reviews were excluded from the study.

Due to the lack of financial resources to access articles that were not available in full in the data sources or translate studies into languages that the researchers did not master (English, Spanish, Portuguese and French), the criterion of contacting the author to have access to it or request the English version was established before excluding them from the study.

Study selection took place in two stages. In the first, studies were selected by reading all titles and abstracts, in order to identify studies that met the defined eligibility criteria. After the initial selection by titles and abstracts, studies were cataloged using Microsoft Excel ${ }^{\oplus}$. Duplicate studies were considered only once. Subsequently, the full reading of each of the selected studies was performed to confirm the relevance of the review question and, if so, extract the data.

Two researchers (HSJ; SL), independently, participated from the initial phase of the study and carried out the two stages of selection. For inclusion, a consensus among researchers was established as necessary. Disagreements were discussed and resolved through consensus. When there was no consensus, a third researcher, who also participated in the previous steps, performed the analysis (BCCGA).

After defining the study sample, a back search was performed, defined in this study as a review of the references of all included studies to identify other studies that could also meet the selection criteria.

\section{Procedures for Data Extraction and SUMMARIZATION}

All studies included in this SR were subjected to methodological quality analysis using JBI critical assessment tools ${ }^{(10)}$. The grade of recommendation and level of evidence were established according to the classification developed by the Oxford Center for Evidence Based Medicine ${ }^{(13)}$. 
The extrication was based on the following variables and information: production characterization data on publication identification (material title, authors, country of origin, language/ data source, year of publication); name of the scientific journal or publication vehicle; methodological aspects of the study (method used, type of approach and study objective or research question, population and sample size); results; limitations and conclusions; level of evidence; and grade of recommendations.

The extracted data were synthesized according to the question and objective of the study. The identification and registration of articles occurred sequentially according to reading order and data collection.

\section{RESULTS}

An initial total of 3,537 documents was obtained through the search strategy in the data sources adopted. After reading all titles and abstracts, 3,463 documents were excluded for not answering the guiding question or not addressing the object under study, and 25 studies, due to duplicity.

Thus, 49 studies were read in full, of which 20 did not answer the study question. Therefore, 29 studies were included in the final sample. After analyzing the references of the 29 included studies, four were added. The final sample consisted of 33 studies. The process of searching and selecting articles from the data sources is illustrated in the flowchart in Figure 1.

The 29 articles (except gray literature) from the final sample are presented in Chart 3 below, with data from the study design, database that was retrieved, grade of recommendation and level of scientific evidence.

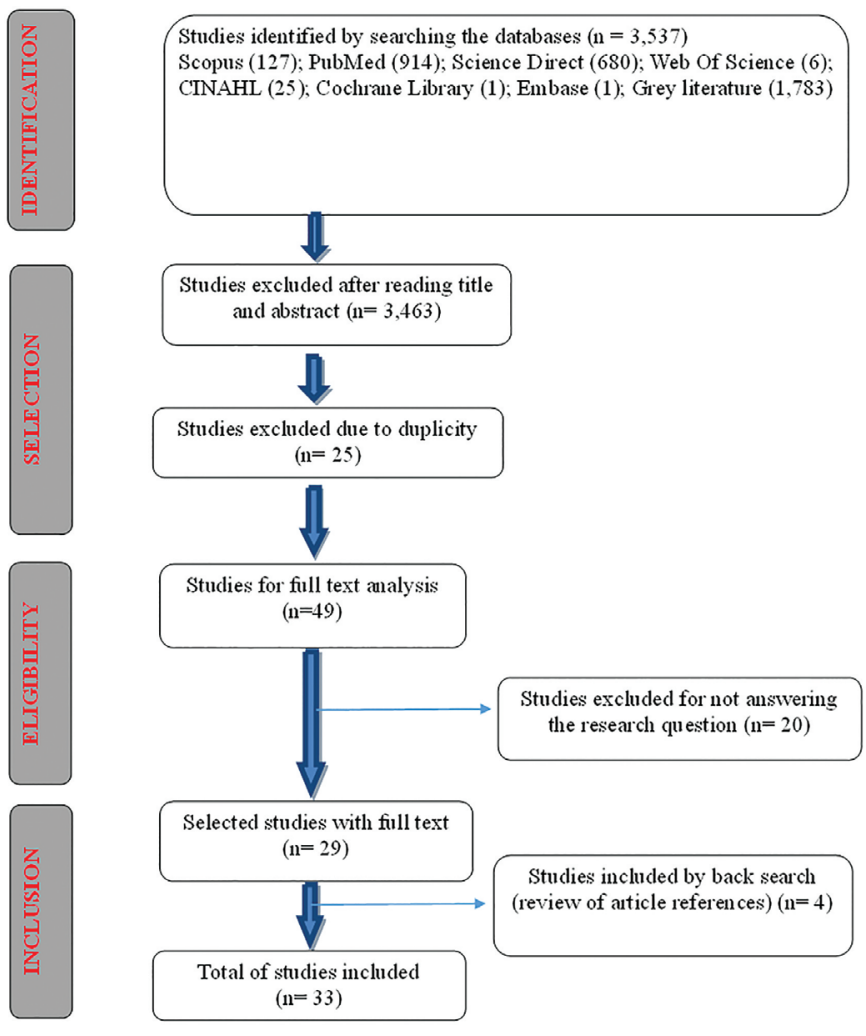

Figure 1 - Flowchart for selecting publications in data sources, Campo Grande/MS 2021.
From gray literature search, four book chapters were included with reference to spinal cord trauma treatment, techniques for extricating victims or devices, with a Brazilian production, two North American and one Portuguese, which are presented in Chart 4.

The time interval of the retrieved studies ranged from 1969 to 2019. In 2013, six (20\%) studies were produced, followed by four (13.3\%) in 2016. With 16 studies (53.3\%), the States United of America was the country that presented the most recovered productions. The MEDLINE/PubMed data source had eleven (44\%) selected publications. Of the studies analyzed, the general population showed a correlation with victims who suffer trauma, the concept deals with the techniques and devices used during treatment and the context refers to the pre-hospital environment. The twentynine studies selected by the data sources were assessed for the level of evidence and grade of recommendation proposed by JBI's own methodology.

\section{EXTRICATION TECHNIQUES}

Based on clinical assessment, extrication techniques can be defined as immediate ${ }^{(14-15)}, \operatorname{rapid}^{(16-17)}$, controlled ${ }^{(18)}$ and selfextrication $^{(19)}$. Immediate extrication occurs when the criterion for choice prioritizes the maintenance of life over possible injuries. In situations that require patient resuscitation or acute external danger is configured for the affected person or for the rescue team, Rautek rescue handle can be used ${ }^{(19)}$.

Rapid extrication considers the clinical condition critical or with evidenced deterioration. During the initial clinical assessment, any finding of a life-threatening alteration, such as deterioration in the level of consciousness or hemodynamic instability, requires rapid intervention. It is essential that the victim is removed from the vehicle within 10 minutes $^{(18,20)}$, with the cervical spine immobilized on a rigid board ${ }^{(21)}$. Rapid extrications are implemented when a critical patient is hemodynamically unstable and the time variable influences the prognosis $^{(39)}$, as it is difficult to administer acute care inside an accidental vehicle and the blockage caused by hardware delays extrication and transportation for definitive care ${ }^{(14)}$.

In turn, clinically stable patients, with no change in the level of consciousness and who may have injuries that do not make them unable to exit the vehicle ${ }^{(18,21)}$ can be removed in a controlled manner ${ }^{(23)}$. Attention should be paid to the neutral alignment of the spine ${ }^{(24,26,43)}$ and promotion of extrication and prevention of spinal and pelvic rotations ${ }^{(23-24,27)}$.

In situations where the patient does not have injuries that make him unable to exit the vehicle, self-extrication can be performed. The stable hemodynamic condition, the identification of low and high risk criteria and the ability to rotate the neck $45^{\circ}$ indicate that the victim can leave the vehicle voluntarily by obeying commands that can help ${ }^{(19)}$.

Manual in-line stabilization of the cervical spine, if possible, should be performed immediately upon arrival in a trauma patient, maintained throughout the primary assessment $(\mathrm{ABCDE})$ and treatment of the trauma patient ${ }^{(19)}$. In patients who need immediate attention for airway maintenance, manual in-line stabilization should be maintained at all times ${ }^{(15,19)}$. 
Chart 3 - Characterization of publications retrieved in database and reference search - Campo Grande, MS, Brazil, 2021 ( $n=29$ ).

\begin{tabular}{|c|c|c|c|}
\hline Title & Study design & Data source & $\begin{array}{l}\text { Grade of recommendation/ } \\
\text { Level of Evidence }\end{array}$ \\
\hline Prehospital care: the extrication patient ${ }^{(14)}$ & Literature review & MEDLINE/PubMed & $\mathrm{NA} * *$ \\
\hline $\begin{array}{l}\text { Evaluation and management of acute cervical spine } \\
\text { trauma }^{(15)}\end{array}$ & Literature review & Scopus & $\mathrm{NA}^{* *}$ \\
\hline Spinal Cord Injury (SCI) - Prehospital Management ${ }^{(16)}$ & Literature review & Science Direct & $N A^{* *}$ \\
\hline $\begin{array}{l}\text { Prehospital Extrication Techniques: Neurological } \\
\text { Outcomes Associated with the Rapid Extrication Method } \\
\text { and the Kendrick Extrication Device }{ }^{(17)}\end{array}$ & Literature review & Scopus & $\mathrm{NA}^{* *}$ \\
\hline Extrication of the seriously injured road crash victim ${ }^{(18)}$ & Literature review & MEDLINE/PubMed & NA** \\
\hline On-scene treatment of spinal injuries in motor sports ${ }^{(19)}$ & Observational & Web of Science & Grade $\mathrm{B} / 3 \mathrm{e}$ \\
\hline Vehicle entrapment rescue and prehospital trauma ${ }^{(20)}$ & Retrospective observational & MEDLINE/PubMed & Grade $B / 3 e$ \\
\hline $\begin{array}{l}\text { Towards evidence-based emergency medicine: best BETS } \\
\text { from the Manchester Royal Infirmary }\end{array}$ & Literature review & MEDLINE/PubMed & $\mathrm{NA} * *$ \\
\hline $\begin{array}{l}\text { Confirmation of suboptimal protocols in spinal } \\
\text { immobilization? } ?^{(22)}\end{array}$ & Retrospective observational & Web of Science & Grade B/3e \\
\hline Spinal injuries and fractures ${ }^{(23)}$ & Literature review & MEDLINE/PubMed & $\mathrm{NA}^{* *}$ \\
\hline $\begin{array}{l}\text { Prehospital management of spinal trauma - An } \\
\text { evolution }^{(24)}\end{array}$ & Literature review & CINAHL & $\mathrm{NA} * *$ \\
\hline $\begin{array}{l}\text { Initial management of the patient with cervical spine } \\
\text { injury }^{(25)}\end{array}$ & Literature review & MEDLINE/PubMed & $\mathrm{NA}^{* *}$ \\
\hline $\begin{array}{l}\text { Wilderness Medical Society Clinical Practice guideline } \\
\text { for spinal cord protection }{ }^{(26)}\end{array}$ & Literature review & Science Direct & NA** \\
\hline $\begin{array}{l}\text { Protection of the spinal cord during stabilization of vital } \\
\text { functions and extrication of trauma victims*(27) }\end{array}$ & Literature review & Back search $^{(17)}$ & $N A^{* *}$ \\
\hline A Review of spinal immobilization techniques ${ }^{(28)}$ & Literature review & MEDLINE/PubMed & $\mathrm{NA}^{* *}$ \\
\hline Cervical spine motion during extrication ${ }^{(29)}$ & Observational & CINAHL & Grade $B / 3 e$ \\
\hline $\begin{array}{l}\text { Rapid extrication versus Kendrick extrication device } \\
\text { (KED) - Comparison of techniques used after motor } \\
\text { vehicle collisions }^{(30)}\end{array}$ & Observational & MEDLINE/PubMed & Grade $\mathrm{B} / 3 \mathrm{e}$ \\
\hline $\begin{array}{l}\text { Can an out-of-hospital cervical spine clearance protocol } \\
\text { identify all patients with injuries? An argument for } \\
\text { selective immobilization }^{(31)}\end{array}$ & Literature review & MEDLINE/PubMed & $\mathrm{NA}^{* *}$ \\
\hline Cervical spine evaluation in the bluntly injured patient ${ }^{(32)}$ & Literature review & Scopus & $\mathrm{NA} * *$ \\
\hline $\begin{array}{l}\text { Articles that may change your practice - spinal } \\
\text { immobilization }^{(33)}\end{array}$ & Literature review & Scopus & $\mathrm{NA} * *$ \\
\hline $\begin{array}{l}\text { The use of clinical cervical spine clearance in trauma } \\
\text { patients: a literature Review }{ }^{(34)}\end{array}$ & Systematic review & Web of Science & Grade $\mathrm{B} / 4 \mathrm{a}$ \\
\hline $\begin{array}{l}\text { Analysis of prehospital care and emergency room } \\
\text { treatment of patients with acute traumatic spinal } \\
\text { cord injury: a retrospective cohort study on the } \\
\text { implementation of current guidelines }{ }^{(35)}\end{array}$ & $\begin{array}{l}\text { Retrospective observational } \\
\text { cohort }\end{array}$ & Scopus & Grade $\mathrm{B} / 3 \mathrm{e}$ \\
\hline $\begin{array}{l}\text { Spinal immobilization for trauma patients (Systematic } \\
\text { Review)*(36) }\end{array}$ & Systematic review & Back search ${ }^{(34)}$ & Grade A/4a \\
\hline $\begin{array}{l}\text { A novel first aid stretcher for immobilization and } \\
\text { transportation of spine injured patients }{ }^{(37)}\end{array}$ & Observational & Science Direct & Grade $\mathrm{B} / 3 \mathrm{e}$ \\
\hline $\begin{array}{l}\text { Development of a new emergency medicine spinal } \\
\text { immobilization protocol for trauma patients and a test of } \\
\text { applicability by German emergency care providers*(38) }\end{array}$ & Observational & Back search $^{(19)}$ & Grade $\mathrm{B} / 3 \mathrm{e}$ \\
\hline $\begin{array}{l}\text { Biomechanical analysis of spinal immobilization during } \\
\text { prehospital extrication: a proof of concept study*(39) }\end{array}$ & Observational & Back search $^{(22)}$ & Grade B/3e \\
\hline Cervical collar placement algorithm for triage nurses ${ }^{(40)}$ & Qualitative observational & MEDLINE/PubMed & Grade $\mathrm{B} / 3 \mathrm{e}$ \\
\hline ABC of major trauma. Transport of injured patients ${ }^{(41)}$ & Literature review & Science Direct & $\mathrm{NA}^{* *}$ \\
\hline Assessing attitudes toward spinal immobilization ${ }^{(42)}$ & Observational & MEDLINE/PubMed & Grade B/3e \\
\hline
\end{tabular}

* Article included by back search. ${ }^{* *} \mathrm{NA}-$ not applied $^{(13)}$. 
Chart 4 - Characterization of publications retrieved through gray literature search - Campo Grande, MS, Brazil, $2020(n=4)$.

\begin{tabular}{|c|c|c|}
\hline Book title & Chapter/chapter page & Country/year \\
\hline $\begin{array}{l}\text { PHTLS: Prehospital } \\
\text { Trauma Life Support }{ }^{(43)}\end{array}$ & 11 - Spinal cord trauma - 300 & $U_{S A}^{* * *} / 2019$ \\
\hline $\begin{array}{l}\text { ATLS: Advanced } \\
\text { Trauma Life Support }{ }^{(44)}\end{array}$ & $\begin{array}{l}7-\text { Spine and spinal cord } \\
\text { trauma }-129\end{array}$ & USA/2018 \\
\hline $\begin{array}{l}\text { Enfermagem no } \\
\text { trauma: atendimento } \\
\text { pré e intra-hospitalar }{ }^{(45)}\end{array}$ & $\begin{array}{l}13 \text { - Imobilização e extricação } \\
\text { do paciente politraumatizado - } \\
283\end{array}$ & Brazil/2019 \\
\hline $\begin{array}{l}\text { Instituto Nacional de } \\
\text { Emergências Médicas - } \\
\text { INEM }\end{array}$ & $\begin{array}{l}\text { Técnicas de Extrication e } \\
\text { Imobilização**** }\end{array}$ & Portugal/2012 \\
\hline
\end{tabular}

*** United States of America; ${ }^{* * * *}$ Specific book on the theme.

\section{Devices for Extrication Aid}

Regarding the devices used to assist in the victim's extrication, according to the retrieved studies, cervical collar ${ }^{(15-16,24-25,28-36)}$, long spine board ${ }^{(14-16,24-26,28-31,33,36)}$, short spine board ${ }^{(14,29-31)}$, head block ${ }^{(15-16,24,33)}$, vacuum stretcher ${ }^{(16,26,35-37)}$, scoop stretcher ${ }^{(14,26,28)}$, and Kendrick Extrication Device (KED) stand out ${ }^{(15-16,22,25-26,30,36)}$.

The cervical collar has been described as a standard device for immobilizing patients in a neutral supine position (dorsal position) ${ }^{(28-29,40)}$. The neutral supine position is defined as the normal anatomical position of the head and trunk when standing and facing forward ${ }^{(25)}$. It should be used to restrict the movement of the cervical vertebrae and thereby protect spinal injuries ${ }^{(41)}$ and prevent the progression of damage, due to its ability to reduce extension, flexion, rotation and lateralization movements ${ }^{(35)}$. Ideally, it should be placed by two professionals because, while one stabilizes the spine, the other applies $i^{(25)}$. The cervical collar can also be applied to the patient's neck while he or she is still in the vehicle ${ }^{(23)}$.

The spine board can be long or short and can be used in conjunction with other devices ${ }^{(16,24-25,28)}$. Also known as a standard backrest, the spine board is a device measuring approximately 1.80 meters in length, rigid and inflexible ${ }^{(30)}$ used to immobilize victims in a neutral supine position ${ }^{(15-16,24,26,29-31,33)}$. The patient is secured to it using three or more straps and two large foam blocks adjacent to the head, referred to as head block devices $^{(15-16,24,29,33)}$.

Head blocks are commonly referred to as cervical blocks or immobilization devices ${ }^{(34,44)}$. In the past, sandbags were used on both sides of the head in conjunction with a spine board. However, this practice has been abolished as they can slip and cause loss of neutral alignment ${ }^{(24)}$. It should be noted that immobilization on a long spine board is not the preferred method and, therefore, emergency service providers often perform spinal immobilization with injury mechanism as the only indication ${ }^{(42)}$.

$\mathrm{KED}^{(21,24,37-39)}$ is a low-flexibility device that fixes the patient's trunk, legs and head in order to prevent movement. It consists of three straps on the torso, an additional strap for the groin and another strap that goes over the forehead. The back of the device is made up of several long blocks of rigid, inflexible material, with a cloth in the middle to allow for flexibility related to the patient's back ${ }^{(30)}$.

It is usually used in patients who are in the driver's position, but it is also an excellent device for pediatric immobilization ${ }^{(44)}$. KED can also be used in conjunction with other immobilization devices ${ }^{(15-16,25-26,30)}$ to extricate victims from vehicles with complaints of pain in the neck or back after vehicle collisions $^{(15,30)}$, as provides immobilization of the head and $\operatorname{trunk}^{(16)}$.

A vacuum stretcher is a flexible polystyrene bag that becomes rigid with the application of the vacuum ${ }^{(37)}$. In Europe, this device, in combination with a rigid neck brace, is a common option for immobilization ${ }^{(16)}$. It provides superior movement restriction and greater comfort for the victim, with the corresponding decreased risk of pressure injury, and is preferred over the spine board for movement restriction of the entire spine or specific segments ${ }^{(19)}$.

The vacuum stretcher device provides insufficient immobilization for the head and neck ${ }^{(37)}$. However, even without cervical collar, but with lateral head support, excellent immobilization can be achieved ${ }^{(19)}$. It is used for spinal trauma victims in conjunction with the spine board, for those who are in confined spaces without vertebral-medullary trauma, as well as in transportation lasting longer than 60 minutes and transportation by helicopter ${ }^{(44)}$.

Scoop stretcher is a device that allows you to fit under the victim without the need to perform a $90^{\circ}$ roll. Composed of two parts, it must be opened by the distal lock, when each part is inserted from below the victim ${ }^{(38)}$. It can be used for transportation and transfer of patients ${ }^{(14)}$. This device is also known as a scoop stretcher ${ }^{(46)}$, indicated to transfer the victim (whose injury mechanism suggests spinal trauma) to the appropriate immobilization device ${ }^{(44)}$.

\section{DISCUSSION}

The choice of devices and techniques to extricate car accident victims was initially based on consensual practice based on historical precedents. The questions came from previously used procedures that were confirmed or scientifically refuted, as over the years and advances in science there is a consolidation of actions with EBP.

According to current pre-hospital practice, the use of rigid cervical collar, long spine board, tie rods ${ }^{(28,33)}$ and head blocks ${ }^{(33,46)}$ in all trauma victims with suspected spinal cord injury is considered a spinal immobilization protocol. The term spinal immobilization, in their care practice for vertebralmedullary trauma, is discouraged and, instead, Spinal Motion Restriction (SMR) is used, because it is recognized that spinal immobilization is not possible in practice and that restricted movement is likely to achieve the same goal ${ }^{(47-48)}$.

It was believed that the practice of taking a patient, victim of multiple trauma, to the emergency room of a reference hospital, as recommended by Advanced Trauma Life Support (ATLS), would comply with immobilization protocols ${ }^{(49)}$. The logic of this practice is to associate that immobilization would prevent neurological deterioration in unstable injuries. However, the effectiveness of PHC and the method 
of immobilization and transportation are not associated with neurological deterioration ${ }^{(26)}$.

It is noteworthy that establishing rigid immobilization protocols was based on a consensus justified by medical position, when applying the cervical collar and long spine board in the treatment of all patients suspected of having spinal cord injury ${ }^{(50-52)}$. The perception of paramedics' difficulty in not recognizing a spinal injury strengthened the excessive and indiscriminate use of the collar and long spine board during immobilization, especially because it only took into account the mechanism of injury ${ }^{(53)}$.

Gradually, the consensus-based practice of using the spine board in all victims with suspected spinal cord injury began to be questioned in the 1980s, as harmful effects have been reported and categorized, when symptoms such as increased pain, respiratory compromise, tissue rupture and ineffective immobilization become prevalent ${ }^{(54)}$.

Furthermore, studies also show that collar use is associated with increased intracranial pressure, difficulty in managing the airways and the presentation of significant morbidity (pain, discomfort, dyspnea and pressure injury) in its prolonged use $^{(19,21,34-35)}$. However, in situations of penetrating trauma with hemodynamic instability, immobilization with the collar is not necessary, as it has a direct relationship with increased mortality ${ }^{(32,43)}$.

In order not to compromise circulation and airway management, the cervical collar must be properly selected ${ }^{(25,34,41)}$. As this device is not capable of providing full spinal immobilization $^{(35)}$, it is usually used in conjunction with others for immobilization ${ }^{(15-16,25-26,30-31)}$. However, this practice has been questioned, as there is little evidence to indicate its effectiveness in immobilization ${ }^{(26)}$. The damage that can be caused by cervical collars is increasingly documented and the risks may outweigh the benefits ${ }^{(48-49)}$.

Although the long and short rigid boards allow for faster extrication of victims, they do not provide complete spinal immobilization $^{(14)}$. In this way, if necessary, rigid boards and other rigid transportation devices can be used for temporary patient movement. However, this information is still not a consensus, as studies indicate that it should not be applied as a medical tool with immobilization goal ${ }^{(26,54)}$. Thus, the transfer of the victim from where he or she is to the spine board must be done by lifting and sliding ${ }^{(20,26)}$.

In a systematic review, the effects of pre-hospital immobilization in healthy individuals were examined. It was found that, although cervical collars, rigid boards, vests, vacuum stretchers and tie rods provided a significant reduction in spinal movement, immobilization could also result in adverse effects such as increased respiratory effort, skin ischemia, pain and discomfort ${ }^{(36)}$.

Decreased lung function was related to chest fixation by straps ${ }^{(55)}$. Tissue maceration was evidenced with prolonged immobilization on spine board ${ }^{(56)}$. In addition to the pain symptoms reported 24 hours after the patient remained immobilized for one hour ${ }^{(57)}$, an increase in the pain score was also observed in participants immobilized on a spine board when compared to the use of a vacuum stretcher ${ }^{(58)}$.

KED is another device used to extricate car accident victims. A radiographic comparison showed superior immobilization of the normal cervical spine during car extrication with this device plus the use of a cervical collar compared to a spine board, tape, and collar ${ }^{(19)}$. If the desire is simply restriction of movement, it is likely that many options are equally viable ${ }^{(19)}$. However, the controversy over its use was reported in another study ${ }^{(39)}$.

The limitation for choosing KED is directly related to anthropometric measurements. Both body mass and height were independent predictors of movement in a model that included the extrication technique as a factor. The strongest correlation during device placement and extrication was between cervical spine movements, mass, and victim height. Tall and obese victims showed more spinal movement ${ }^{(39)}$.

Immobilization of the potentially injured spine with a vacuum stretcher device is the current recommendation of the International Commission for Mountain Emergency Medicine for transportation of trauma victims ${ }^{(26)}$. Studies have shown that the vacuum stretcher provides significantly greater spine stability, greater speed of application and greater patient comfort ${ }^{(19,26,35)}$ when compared to a spine board ${ }^{(34)}$ or only the cervical collar ${ }^{(59)}$. On the other hand, the scoop stretcher showed better results in relation to spinal misalignment ${ }^{(36)}$.

During the initial assessment of the victim with potential spinal injury, the identification of hemodynamic signs ${ }^{(17,22,24)}$, neurological deficits ${ }^{(23,37,40,42)}$, sensory and motor disorders ${ }^{(31,40)}$ and other signs of injury ${ }^{(17)}$ must be ensured in order to establish priorities in choosing the appropriate technique and device $^{(40)}$. After the initial approach and primary and secondary assessment ${ }^{(37)}$, the sequence of immobilization, extrication and transportation of victims to a trauma treatment referral center $^{(35,40,43-46)}$, completes the order of care.

Hemodynamic conditions ${ }^{(17)}$, neurological status ${ }^{(19,49)}$, and identification of injuries ${ }^{(35)}$ in the patient define the clinical status, with classifications as critical ${ }^{(24)}$, unstable (17,35) $^{(1,1 / \text { or }}$ stable $^{(24)}$. Based on the classification of clinical status, extrication techniques can be defined as immediate ${ }^{(18)}$, $\operatorname{rapid}^{(16-17,30)}$, controlled $^{(22,39)}$ and self-extrication ${ }^{(22,38-39)}$.

With regard to carrying out an immediate extrication, with one or two professionals, the patient's critical condition should be taken into account. Thus, a critically and hemodynamically unstable patient requires rapid extrication as it is difficult to administer acute care within an injured vehicle and the blockage delays transportation for definitive care ${ }^{(14)}$. It is essential that the victim is removed from the vehicle within 10 minutes $^{(18,20)}$, with the cervical spine immobilized on a spine board ${ }^{(21)}$.

In turn, the controlled extrication technique applies to the stabilized victim ${ }^{(8,18)}$. The cervical collar must be applied and the extrication consists of the in-line exit through the trunk lid of vehicles with the use of a long spine board ${ }^{(22)}$. During extrication, the technique called zero angle aims to maintain the neutral alignment of the spine and seek the lowest angle (in-line extrication) of movement of the injured person, a preponderant factor to avoid the aggravation of injuries ${ }^{(8,22,39)}$. In order to comply with the principles of maintaining neutral alignment, less angulation of movements and avoiding spine twist, the scoop stretcher can be used to replace the long spine board $^{(14,46)}$.

Only victims without immediate threat to life should be fully immobilized before removal ${ }^{(14,38)}$. Regarding the time of 
the scene, manually immobilizing the cervical spine in line, applying semi-rigid cervical collars and extrication devices that immobilize the entire spine are recognition of the fact that full spinal immobilization can considerably prolong rescue times and scene ${ }^{(54)}$.

A study found that high-speed collisions resulted in $27.7 \%$ of patients suffering spinal injuries and $66.0 \%$ had traumatic brain injuries. However, entrapment was reported to occur in only $12 \%$ to $33 \%$ of road traffic collisions (RTC) and many patients were eligible for self-extrication, depending on their clinical condition ${ }^{(22)}$.

In circumstances where patients have stable hemodynamic conditions, the patient can be induced to leave the car on their own. A study carried out with a team of two paramedics and four firefighters, when performing the extrication of $16 \mathrm{immo-}$ bilized patients from a vehicle, identified that the technique that least moved the spine was, in ascending order, self-extrication (1333), in-line extrication with spine board (1356), selfextrication with instruction (14093) and use of $\operatorname{KED}\left(17^{\circ} 60\right)^{(22)}$. Thus, the self-extrication technique produces less movement of the cervical spine compared to other techniques ${ }^{(22,24)}$. However, in patients who experience pain or injuries that disable them during exiting the vehicle, self-extrication is not indicated ${ }^{(22)}$.

No studies were found whose damage was caused by failure of a cervical collar or spine board, but growing evidence, both real and theoretical, that the placement of these devices can cause damage has been identified. Furthermore, with clear instructions, patients seem able to maintain a stable neck for removal the cervical collar ${ }^{(22)}$.

In assessing the absence of benefits from immobilization techniques, the National Association of EMS Physicians (NAEMSP) in 2013 recommended milder measures to manage patients with suspected spinal injury. In the same vein, the American College of Emergency Physicians (ACEP) published a statement that confirmed that it was not possible to immobilize the spine. Statements published by the institutions confirmed that the purpose of the long spine board is to be used as an extrication device and should be removed as soon as possible ${ }^{(54)}$.

Within the context of the positioning of the National Association of EMS Physicians (NAEMSP) and the American College of Surgeons Committee on Trauma (ACSCOT), emergency medical services started to use SMR based on physical examination ${ }^{(60)}$. With the implementation of evidence in decision-making, it is inferred that the clinical evaluation process for choosing the devices and techniques for extrication of victims are associated with the use of tools that facilitated the exclusion of spinal cord trauma in the inhospital environment.

The main tools used by traumatologists to clinically confirm the absence of cervical spine injuries, without the need for imaging, are the National Emergency X-Radiography Utilization Study (NEXUS) and the Canadian C-Spine rule $(\mathrm{CCR})^{(61-62)}$. The NEXUS criterion assesses whether the patient is at low risk, in order to ensure that there are no injuries that do not require imaging ${ }^{(63)}$.

The CCR criterion takes into account high risk factors, such as age over 65 years, dangerous mechanism and paresthesia in the extremities ${ }^{(64)}$. If there are no high-risk criteria, lowrisk factors are reviewed to see if the patient can be reliably assessed for range of motion and neck rotation ${ }^{(34)}$. The CCR study had better sensitivity and specificity when compared to the NEXUS study (99\% versus $93 \%$ and $43 \%$ versus $33 \%$, respectively). By using one or both of these rules, it is possible to rule out cervical spine injuries in the most aware, alert and reliable patients ${ }^{(61-62)}$.

During the clinical evaluation, one of the criteria for applying the extrication techniques is to keep the spine in a neutral anatomical position ${ }^{(16,29)}$ and to avoid rotations of the spine and pelvis ${ }^{(27,43)}$. SMR is indicated for victims who have suffered trauma by a mechanism with the potential to cause spinal injury and who have an altered mental state or level of consciousness, evidence of alcohol or drug intoxication, painful distraction injury, neurological signs associated with spinal injury, pain or tenderness in the cervical, thoracic or lumbar spine, and known injury to the spine ${ }^{(38,54,59)}$.

\section{CONCLUSION}

The studies indicated that the use of techniques and devices for extricating automobile collision victims with potential spinal injuries was historically based on successful practices, but without due scientific investigation in order to standardize them. From this perspective, this SR provides a summary of scientific evidence on such techniques for better clinical decision-making.

It is agreed that neutral spinal alignment should be maintained and spine twists should be avoided. In this regard, injury assessment with emphasis on the victim's clinical condition will provide a coherent decision-making regarding the technique and device to be used. Long spine board remains a device used to extract or remove car crash victims. However, its use must occur in a rational, individualized manner and after evaluating the trauma kinematics associated with the mechanism of injury.

Spine board must be removed as soon as possible. Scoop stretcher was indicated as an alternative to extrication, and the vacuum stretcher, for the transportation of victims. The transfer of victims should preferably be performed by lifting, sliding and rolling, in this sequence. The value of routine prehospital spinal immobilization remains uncertain.

Considering the most varied techniques for extracting automobile collision victims mentioned in this SR, the importance of carrying out comparative studies between the existing techniques is indicated, in order to assist in the decision-making process of the technique and the most effective device use.

The study had limitations in accessing studies not available in full, due to the lack of resources to acquire them. Language was also a limiting factor, due to the lack of resources for translation of studies that were not in English, French, Portuguese and Spanish. However, as much as some study may have been excluded due to these limitations, it is believed that they did not reduce the importance of the evidence summarized in this SR that could support the practice of care in PHC. 
RESUMO

Objetivo: sumarizar as técnicas de extração de vítimas de colisão automobilísticas encarceradas com potencial lesão de coluna vertebral. Método: estudo de revisão de literatura, do tipo revisão de escopo, usando as fontes de dados MEDLINE/PubMed, CINAHL, Scopus, Science Direct, Web of Science, Cochrane Library e literatura cinzenta, sem recorte temporal, com estudos que abordaram técnicas de extração de vítimas de colisão automobilística encarceradas. Resultados: foram incluídos 33 estudos, que possibilitaram a identificação e sumarização dos diferentes tipos de extração e respectivos dispositivos para a extração de vítimas de colisão automobilísticas encarceradas, indicados conforme avaliação da lesão e quadro clínico da vítima. Todos apontaram para a necessidade técnica para manutenção do alinhamento neutro e prevenção de torções na coluna vertebral. Conclusão: este estudo indicou que a avaliação da lesão com ênfase no quadro clínico da vítima proporciona uma tomada de decisão coerente quanto à técnica e ao dispositivo a serem utilizados. Entretanto, a realização de outros estudos comparativos entre as técnicas existentes poderá auxiliar no processo de tomada de decisão de forma mais assertiva.

\section{DESCRITORES}

Acidentes de Trânsito; Traumatismos da Medula Espinal; Métodos.

\section{RESUMEN}

Objetivo: resumir las técnicas para extraer a las víctimas de accidentes automovilísticos encarceladas con una posible lesión en la columna. Métodos: estudio de revisión de literatura, tipo revisión de alcance, utilizando las fuentes de datos MEDLINE/PubMed, CINAHL, Scopus, Science Direct, Web of Science, Cochrane Library y literatura gris, sin marco de tiempo, con estudios que abordaron técnicas de extracción de datos. Resultados: se incluyeron 33 estudios que permitieron identificar y resumir los diferentes tipos de extracción y respectivos dispositivos para la extracción de víctimas de accidentes automovilísticos encarcelados, indicados de acuerdo con la valoración de la lesión y el estado clínico de la víctima. Todos señalaron la necesidad técnica de mantener una alineación neutra y prevenir torsiones espinales. Conclusión: este estudio indicó que la valoración de la lesión con énfasis en la condición clínica de la víctima proporciona una toma de decisiones coherente en cuanto a la técnica y dispositivo a utilizar. Sin embargo, la realización de otros estudios comparativos entre las técnicas existentes puede ayudar en el proceso de toma de decisiones de forma más asertiva.

\section{DESCRIPTORES}

Accidentes de Tránsito; Traumatismos de la Médula Espinal; Métodos.

\section{REFERENCES}

1. Paho.org [Internet]. Brasil: Organização Panamericana da Saúde; 2019 [cited 2021 Feb 16]. Available from: https://www.paho.org/bra/index. php?option=com_content\&view=article\&id=5147:acidentes-de-transito-folha-informativa\&ltemid=779.

2. Abulatif LI. Data Integation Process: an information management model for multiple databases on traffic accidents in Brazil. Epidemiol Serv Saúde. 2018;27(2):1-8. DOI: https://doi.org/10.5123/s1679-49742018000200018.

3. Atiksawedpari P, Rattanasiri S, Sittichanbuncha Y, Suriyawongpaisal P, Attia J, Thakkinstian A. Prehospital prediction of severe injury in road traffic injuries: a multicenter cross-sectional study. Injury. 2019;50(9):1499-506. DOI: https://doi.org/10.1016/j.injury.2019.05.028.

4. Kreinest M, Scholz M, Trafford P. On-scene treatment of spinal injuries in motor sports. Eur J Trauma Emerg Surg. 2017;43(2):191-200. DOI: https://doi.org/10.1007/s00068-016-0749-3.

5. Corpo de Bombeiros Militar do Distrito Federal. Boletim de Informação Técnico Profissional №11 e Diretrizes gerais para Atendimento Préhospitalar no Salvamento Veicular. Distrito Federal: CBMDF; 2020.

6. National Fire Protection Association. NFPA 1670: standard on operations and training for technical search and rescue incidents. Quincy: NFPA; 2017.

7. Nutbean T, Fenwick R, Robson C, Holland V, Palmer M. Extrication time prediction tool. Emerg Med J. 2014;32:401-3. DOI: https://doi.org/10.1136/ emermed-2013-202864.

8. Santos EF. Emprego da técnica de ângulo zero na extração de vítimas de acidentes automobilísticos. Emergência [Internet]. 2019 [cited 2021 Feb 16];54-6. Available from: ibraph.com.br/wp-content/uploads/2019/12/RETIRADA-VEICULAR-EDNEI-FERNANDO-REVISTA-EMERGENCIA-2019. pdf.

9. Arksey H, O'Malley L. Scoping studies: towards a methodological framework. International J Soc Res Methodol. 2005;8(1):19-32. DOI: https:// doi.org/10.1080/1364557032000119616.

10. Peters MDJ, Godfrey C, Mclnerney P, Munn Z, Tricco AC, Khalil, H. Chapter 11: Scoping reviews. In: Aromataris E, Munn Z, editors. JBI Manual for evidence synthesis. Adelaide: JBI; 2020 [cited 2021 Apr 14]. Available from: http://synthesismanual.jbi.global.

11. Tricco AC, Lillie E, Zarin W, O'Brien K, Colquhoun H, Levac D, et al. PRISMA extension for scoping reviews (PRISMA-ScR): checklist and explanation. 2018;169(7):467-73. DOI: https://doi.or/10.7326/M18-0850.

12. Mokkink LB, Terweea CB, Patrick DL, Alonso J, Stratford PW, Knol DL, et al. The COSMIN study reached international consensus on taxonomy, terminology, and definitions of measurement properties for health-related patient-reported outcomes. J Clin Epidemiol. 2010;63(7):737-45. DOI: https//doi.org/10.1016/j.jclinepi.2010.02.006.

13. Phillips B, Ball C, Sackett D, Badenoch D, Straus S, et al. Levels of evidence [Internet]. Oxford: CEBM; 2009 [cited 2016 Nov 30]. Available from: https://www.cebm.net/2009/06/oxford-centre-evidence-based-medicine-levels-evidence-march-2009.

14. Mackenzie R, Sutcliffe R. Pre-hospital care: the trapped patient. J R Army Med Corps. 2000;146(1):39-46. DOI: http://dx.doi.org/10.1136/ jramc-146-01-09.

15. Pimentel L, Diegelmann L. Evaluation and management of acute cervical spine trauma. Emerg Med Clin North Am. 2010;28(4):719-38. DOI: https://doi.org/10.1016/j.emc.2010.07.003.

16. Bernhard M, Gries A, Kremer P, Böttiger BW. Spinal cord injury (SCI) - prehospital management. Resuscitation. 2005;66(2):127-39. DOI: https:// doi.org/10.1016/j.resuscitation.2005.03.005. 
17. Misasi A, Ward JG, Dong F, Ablah E, Maurer C, Haan JM. Prehospital extrication techniques: neurological outcomes associated with the rapid extrication method and the Kendrick extrication device. Am Surg. 2018;84(2):248-53. DOI: https://doi.org/10.1177/000313481808400233.

18. Calland V. Extrication of the seriously injured road crash victim. Emerg Med J. 2005;22(11):817-21. DOI: https://doi.org/10.1136/emj.2004.022616.

19. Kreinest M, Scholz M, Trafford P. On-scene treatment of spinal injuries in motor sports. Eur J Trauma Emerg Surg. 2017;43(2):191-200. DOI: https://doi.org/10.1007/s00068-016-0749-3.

20. Wilmink ABM, Samra GS, Watson LM, Wilson AW. Vehicle entrapment rescue and pre-hospital trauma care. Injury. 1996;27(1):21-5. DOI: https:// doi.org/10.1016/0020-1383(95)00162-X.

21. Mackway-Jones K. Best evidence topic report. Towards evidence based emergency medicine: best BETs from the Manchester Royal Infirmary. Emerg Med J. 2006;23(4):300. DOI: http://dx.doi.org/10.1136/emj.2006.035121.

22. Dixon M, O'Halloran J, Hannigan A, Keenan S, Cummins NM. Confirmation of suboptimal protocols in spinal immobilisation? Emergency Medicine Journal. 2015;32:939-45. DOI: https://doi.org/10.1136/emermed-2014-204553.

23. Ashworth J. Spinal injuries and fractures. Br Med J. 1969;4(5680):414-5. DOI: https://doi.org/10.1136/bmj.4.5680.414.

24. Kish DL. Prehospital management of spinal trauma: an evolution. Crit Care Nurs Q. 1999;22(3):36-43; Erratum in: Crit Care Nurs Q. 1999;22(3):vi. DOI: https://doi.org/10.1097/00002727-199908000-00007.

25. Taneja A, Berry CA, Rao RD. Initial management of the patient with cervical spine injury. Seminars in Spine Surgery. 2013;25(1):2-13. DOI: https:// doi.org/10.1053/j.semss.2012.07.005.

26. Hawkins SC, Williams J, Bennett BL, Islas A, Kayser DW, Quinn R. Wilderness Medical Society Clinical Practice Guidelines for Spinal Cord Protection. Wilderness Environ Med. 2019;30(4 Suppl):S87-99. DOI: https://doi.org/10.1016/j.wem.2019.08.001.

27. J Meertens, R Lichtveld. Protection of the spinal cord during stabilisation of vital functions and extrication of trauma victims. The Internet Journal of Rescue and Disaster Medicine. 2000 [cited 2021 Apr 14];2(2). Available from: http://ispub.com/IJRDM/2/2/10166.

28. De Lorenzo RA. A Review of spinal immobilization techniques. J Emerg Med. 1996;14(5):603-13. DOI: https://doi.org/10.1016/S07364679(96)00140-0.

29. Engsberg JR, Standeven JW, Shurtleff TL, Eggars JL, Shafer JF, Naunheim RS. Cervical spine motion during extrication. J Emerg Med. 2013;44(1):122-7. DOI: https://doi.org/10.1016/j.jemermed.2012.02.082.

30. Bucher J, Dos Santos F, Frazier D, Merlin MA. Rapid extrication versus the Kendrick extrication device (KED): comparison of techniques used after motor vehicle collisions. West J Emerg Med. 2015;16(3):453-8. DOI: https://doi.org/10.5811/westjem.2015.1.21851.

31. Stroh G, Braude D. Can an out-of-hospital cervical spine clearance protocol identify all patients with injuries? An argument for selective immobilization. Ann Emerg Med. 2001;37(6):609-15. DOl: https://doi.org/10.1067/mem.2001.114409.

32. Zakrison TL, Williams BH. Cervical spine evaluation in the bluntly injured patient. Int J Surg. 2016;33 Pt B:246-50. DOI: https://doi.org/10.1016/j. ijsu.2016.01.086.

33. MacDonald RD. Articles that may change your practice: spinal immobilization. Air Med J. 2017;36(4):162-4. DOI: https://doi.org/10.1016/j. amj.2017.03.007.

34. Larson S, Delnat AU, Moore J. The use of clinical cervical spine clearance in trauma patients: a literature review. J Emerg Nurs. 2018;44(4):368-74. DOI: https://doi.org/10.1016/j.jen.2017.10.013.

35. Kreinest M, Ludes L, Türk A, Grützner PA, Biglari B, Matschke S. Analysis of prehospital care and emergency room treatment of patients with acute traumatic spinal cord injury: a retrospective cohort study on the implementation of current guidelines. Spinal Cord. 2017;55(1):16-9. DOI: https://doi.org/10.1038/sc.2016.84.

36. Kwan I, Bunn F, Roberts I. Spinal immobilisation for trauma patients. Cochrane Database Syst Rev. 2001;2001(2):CD002803. DOI: https://doi. org/10.1002/14651858.CD002803.

37. Yan-Sheng L, Ya-Ping F, Jia-Xin X, Zhuo-Jing L, Cai-Hong S, Fang N, et al. A novel first aid stretcher for immobilization and transportation of spine injured patients. PLoS One. 2012;7(7):e39544. DOI: https://doi.org/10.1371/journal.pone.0039544.

38. Kreinest M, Gliwitzky B, Schüler S, Grützner PA, Münzberg M. Development of a new Emergency Medicine Spinal Immobilization Protocol for trauma patients and a test of applicability by German emergency care providers. Scand J Trauma Resusc Emerg Med. 2016;24:71. DOI: https:// doi.org/10.1186/s13049-016-0267-7.

39. Dixon M, O'Halloran J, Cummins NM. Biomechanical analysis of spinal immobilisation during prehospital extrication: a proof of concept study. Emerg Med J. 2014;31:745-9. DOI: http://dx.doi.org/10.1136/emermed-2013-202500.

40. Irwin M, Foley AL. Cervical collar placement algorithm for triage nurses. J Emerg Nurs. 2018;44(6):668-70. DOI: https://doi.org/10.1016/j. jen.2018.08.009.

41. Wilson A, Driscoll P. ABC of major trauma. Transport of injured patients. BMJ. 1990;301(6753):658-62. DOI: https://doi.org/10.1136/ bmj.301.6753.658.

42. Bouland AJ, Jenkins JL, Levy MJ. Assessing attitudes toward spinal immobilization. J Emerg Med. 2013;45(4):e117-25. DOI: https://doi.org/10.1016/j. jemermed.2013.03.046.

43. National Association of Emergency Medical Technicians (NAEMT). PHTLS: atendimento pré-hospitalar ao traumatizado. $8^{\mathrm{a}}$ ed. Burlington: Jones \& Bartlett Learning; 2016.

44. American College of Surgeons Committee on Trauma. Advanced Trauma Life Support - ATLS: student course manual. 10 a ed. Chicago: American College of Surgeons; 2018.

45. Borges AS, Andrade AR, Chocron MAP, Neto JHM. Imobilização e extricação do paciente politraumatizado. In: Dos Santos MN, Silva WP, editors. Enfermagem no trauma: atendimento pré e intra-hospitalar. Porto Alegre: Moriá; 2019. 
46. Instituto Nacional de Emergências Médicas (INEM). Técnicas de extração e imobilização de vítimas de trauma. $2^{a}$ ed. Sintra: INEM; 2012 [cited 2021 Apr 14]. Available from: inem.pt/wp-content/uploads/2017/06/Técnicas-de-Extração-e-Imobilização-de-Vítimas-de-Trauma.pdf.

47. Porter A, Difrancesca M, Slack S, Hudecek L, Mclntosh SE. Improvised vs standard cervical collar to restrict spine movement in the backcountry environment. Wilderness Environ Med. 2019;30(4):412-6. DOI: https://doi.org/10.1016/j.wem.2019.07.002.

48. Stanton D, Hardcastle T, Muhlbauer D, D van Zyl. Cervical collars and immobilisation: A South African best practice recommendation. Afr J Emerg Med. 2017;7(1):4-8. DOI: https://doi.org/10.1016/j.afjem.2017.01.007.

49. Damiani D. Routine cervical collar use in polytrauma patients: a critical review. Rev Soc Bras Clin Med. 2017 [cited 2021 Apr 14];15(2):131-6. Available from: http://docs.bvsalud.org/biblioref/2017/11/875615/152_131-136.pdf.

50. Kossuth LC. The removal of injured personnel from wrecked vehicles. J Trauma. 1965;5(6):703-8. DOI: https://doi.org/10.1097/00005373196511000-00004.

51. Kossuth LC. Vehicle accidents: immediate care to back injuries. J Trauma. 1966;6(5):582-91.

52. Farrington JD. Extrication of victims-surgical principles. J Trauma. 1968;8(4):493-512.

53. Riggins RS, Kraus JF. The risk of neurologic damage with fractures of the vertebrae. J Trauma. 1977; 17(2):126-33. DOI: https://doi. org/10.1097/00005373-197702000-00007.

54. Feld FX. Removal of the long spine board from clinical practice: a historical perspective. J Athl Train. 2018;53(8):752-55. DOI: https://doi. org/10.4085/1062-6050-462-17.

55. Bauer D, Kowalski R. Effect of spinal immobilization devices on pulmonary function in the healthy, nonsmoking man. Ann Emerg Med. 1988;17(9):915-8. DOI: https://doi.org/10.1016/s0196-0644(88)80671-1.

56. Cordell WH, Hollingsworth JC, Olinger ML, Stroman SJ, Nelson DR. Pain and tissue-interface pressures during spine-board immobilization. Ann Emerg Med. 1995;26(1):31-6. DOI: https://doi.org/10.1016/S0196-0644(95)70234-2.

57. Chan D, Goldberg R, Tascone A, Harmon S, Chan L. The effect of spinal immobilization on healthy volunteers. Ann Emerg Med. 1994;23(1):48-51. DOI: https://doi.org/10.1016/s0196-0644(94)70007-9.

58. Cross DA, Baskerville J. Comparison of perceived pain with different immobilization techniques. Prehosp Emerg Care. 2001;5(3):270-4. DOI: https://doi.org/10.1080/10903120190939779.

59. Rahmatalla S, De Shaw J, Stilley J, Denning G, Jennissen C. Comparing the efficacy of methods for immobilizing the cervical spine. Spine. 2019;44(1):32-40. DOI: https://doi.org/10.1097/BRS.0000000000002749.

60. National Association of EMS Physicians, American College of Surgeons Committee on Trauma. EMS spinal precautions and the use of the long backboard. Prehosp Emerg Care. 2013;17(3):392-3. DOI: https://doi.org/10.3109/10903127.2014.884197.

61. Stiell IG, Clement CM, McKnight RD, Brison R, Schull MJ, Rowe BH, et al. The Canadian C-spine rule versus the NEXUS low-risk criteria in patients with trauma. N Engl J Med. 2003;349(26):2510-8. DOI: https://doi.org/10.1056/NEJMoa031375.

62. Vinson DR. Nexus cervical spine criteria. Ann Emerg Med. 2001;37(2):237-8. DOI: https://doi.org/10.1067/mem.2001.112728.

63. Sundstrom T, Asbjornsen H, Habiba S, Sunde GA, Wester K. Prehospital use of cervical collars in trauma patients: a critical review. J Neurotrauma. 2014;31(6):531-40. DOI: https://doi.org/10.1089/neu.2013.3094.

64. Denver D, Shetty A, Unwin D. Falls and implementation of NEXUS in the elderly (The FINE study). J Emerg Med. 2015;49(3):294-300. DOI: https:// doi.org/10.1016/j.jemermed.2015.03.005.

\section{Financial support}

Fundação Universidade Federal de Mato Grosso do Sul - UFMS/MEC - Brazil and the Coordination for the Improvement of Higher Education Personnel - Brazil (CAPES - Coordenação de Aperfeiçoamento de Pessoal de Nível Superior) - Financing Code 001. 